OPEN ACCESS

Edited by:

Sophia N. Wassermann, University of California, Davis,

United States

Reviewed by:

Joanne Irene Ellis,

University of Waikato, New Zealand

Charalampos Dimitriadis,

National Marine Park of Zakynthos,

Greece

*Correspondence:

Rafael Almeida Magris

Rafael.magris@icmbio.gov.br

Specialty section

This article was submitted to

Marine Conservation

and Sustainability,

a section of the journal

Frontiers in Marine Science

Received: 17 May 2021

Accepted: 26 July 2021

Published: 24 August 2021

Citation:

Magris RA (2021) Effectiveness of Large-Scale Marine Protected

Areas in the Atlantic Ocean

for Reducing Fishing Activities.

Front. Mar. Sci. 8:711011. doi: 10.3389/fmars.2021.711011

\section{Effectiveness of Large-Scale Marine Protected Areas in the Atlantic Ocean for Reducing Fishing Activities}

\author{
Rafael Almeida Magris* \\ Chico Mendes Institute for Biodiversity Conservation, Ministry of Environment, Brasilia, Brazil
}

The implementation of large-scale marine protected areas (MPAs) depends upon scarce conservation resources, while their effects on biodiversity conservation are rarely assessed to date. Quantitative evaluations are necessary to assess the effectiveness of large-scale MPAs in enhancing ecosystem resilience, protecting biodiversity, and mitigating expanding threats. In this study, the effectiveness of large-scale MPAs, which are remotely managed and in offshore areas of the southwestern Atlantic Ocean (Brazil), was assessed concerning the occurrence of fishing activities within their boundaries before and after their implementation. Two sets of MPAs surrounding the São Pedro and São Paulo archipelago (SPSP) and the Trindade-Martin Vaz Islands (TMV) were established in early 2018, each comprising one no-take (i.e., fully-protected) and one multiple-use (i.e., partially-protected) area. For this assessment, I used satellite detections of Vessel Monitoring System transmission to quantify the fishing pressure (i.e., "likely fishing days") from commercial fisheries spanning 5 years (2015-2019). I then derived three metrics - fishing area, intensity, and density - to compare fishing activity within each MPA and year. The results showed that the effectiveness of the multiple-use MPAs was variable and contrasting, with SPSP experiencing a reduction in the fishing intensity and area and TMV experiencing an increase in both measures. An inverted pattern was evident for the no-take MPAs: while the one in the SPSP region experienced an increase in the fishing density after its establishment following a squeeze factor, the no-take MPA in the TMV region observed a decrease in the fishing density when comparing years before and after MPA implementation. These outputs can support managers in planning the implementation of further conservation strategies, such as monitoring and enforcement plans, and the analyses here also contribute to enhancing our understanding on the implications and challenges of adopting large-scale MPAs in the offshore environment as a high-profile strategy of ocean conservation.

Keywords: large marine protected areas, marine conservation, conservation assessment, commercial fishing, vessel tracking, vessel monitoring system, Brazil, fisheries 


\section{INTRODUCTION}

Fishing is a leading cause of disturbances in the marine realm with consequences such as trophic cascade (Mumby et al., 2006; Shears et al., 2008) and loss of habitats (Kaiser et al., 2002; Lundquist et al., 2018). Moreover, overfishing in targeted and by-catch fisheries causes population decline in several species of the megafauna, including sharks, seabirds, and marine mammals (Dulvy et al., 2014; White et al., 2017). The global expansion of fisheries to meet the demand for fisheries resource extraction and the continued development of gear technology both have expanded and intensified the activity, with fishing occurring even in the remotest parts of the ocean (Sala et al., 2018).

Globally, fishing activity requires robust management measures to mitigate its impacts on marine biodiversity. Although there are several frameworks concerned with improving fisheries management (e.g., Booth et al., 2020), the designation of marine protected areas (MPAs) is the most applied tool to maintain biodiversity and fisheries at a sustainable level (Lubchenco and Grorud-Colvert, 2015). Several countries, including Brazil, are making compelling cases for historical progress toward achieving the international targets for marine protection under the Convention on Biological Diversity and the Sustainable Development Goals (Friedlander et al., 2016; Magris and Pressey, 2018; Claudet et al., 2021). As a consequence, recent years have also seen an increase in the development of large-scale MPAs (i.e., larger than $100,000 \mathrm{~km}^{2}$ ) over offshore and deep areas (Boonzaier and Pauly, 2016), following an ad hoc, opportunistic process (O'Leary et al., 2018). However, for these conservation efforts to drive outcomes for biodiversity, they must translate into significant mitigation of human impacts, particularly derived from fishing activity. This requires overcoming the monitoring and enforcement challenges associated with the large-scale governance of dynamic and remote seascapes (De Santo, 2013; Brooks et al., 2019).

Overall, there are several ways of measuring MPA effectiveness, and several frameworks have been proposed (Pomeroy et al., 2005; Pajaro et al., 2010; Zupan et al., 2018a). Percentages of an area under protection (i.e., MPA coverage), although commonly used, are misleading indicators of conservation success (Roberts et al., 2018). Indicators of MPA management effectiveness are intended to show how well MPAs are working towards their objectives (Pajaro et al., 2010), but they are usually evaluated using only managers' perceptions of good governance and MPA impacts (de Oliveira Júnior et al., 2021). Improvements of ecological conditions, such as the increase in species abundance, are seen as more accurate determinants of MPA effectiveness, but evaluations of offshore MPAs in remote areas are difficult due to data paucity and budgetary constraints related to the development of monitoring programs in such areas (Ban et al., 2017). Finally, a quantitative assessment of how well MPAs can abate the threatening processes provides an alternative, practical assessment of effectiveness (Zupan et al., 2018a) until detailed post-implementation monitoring data have been collected.

Vessel Monitoring System (VMS) data can help fill the gap in effectiveness assessments of large-scale, offshore MPAs and are widely used to evaluate fishing activity (Chang and Yuan,
2014; Delfour-Samama and Leboeuf, 2014; Rowlands et al., 2019). VMS can track vessel movements in near real-time using satellite transponders. Although the system is not tamper-proof (Appleby et al., 2018), it might be the only tool available to assess patterns of fishing activity and provides historical valuable information such as the vessel's identity, position, and associated fishing gear. These data can thus provide a unique baseline for determining whether MPAs are effective at reducing threats in the absence of other monitoring tools. Here, I used a longterm, large dataset tracking the movements of commercial fishing vessels before and after the two of the largest MPAs in the southern Atlantic Ocean (within Brazil's exclusive economic zone) were established - i.e., between the years 2015 and 2019 - to provide evidence of their effectiveness at reducing fishing pressure.

\section{METHODS}

\section{Case Study Description}

To meet global MPA commitments and in recognition of the relatively poor development of protected areas associated with the marine realm in Brazil, the Ministry of the Environment declared two sets of large-scale MPAs in the Southwestern Atlantic Ocean in early 2018: (i) two MPAs surrounding the São Pedro and São Paulo Archipelago (SPSP), which is formed by rocky islands in the mid-Equatorial North Atlantic Ocean $\left(0^{\circ} 55^{\prime} \mathrm{N} ; 29^{\circ} 20^{\prime} \mathrm{W}\right)$, distant about $1,000 \mathrm{~km}$ from the mainland; and (ii) two MPAs surrounding the Trindade Island and the Martin Vaz Archipelago (TMV), which is formed by the emerged part of the Vitória - Trindade submarine chain in the southwestern tropical Atlantic Ocean $\left(29^{\circ} 18^{\prime} \mathrm{S} ; 20^{\circ} 30^{\prime} \mathrm{W}\right)$, distant $1,160 \mathrm{~km}$ from the mainland (see Supplementary Figure 1 for detailed zoomed views of both regions). These islands have among the highest fish biomass across Brazilian reefs (Morais et al., 2017), notable endemism (Simon et al., 2013; Pinheiro et al., 2020), and globally threatened fauna (Almeida et al., 2011; Duarte-Neto et al., 2012). Despite their biodiversity significance, both regions are also threatened by commercial fisheries and climate change (Magris et al., 2020). The MPAs comprise the territorial sea and exclusive economic zones of the islands.

The no-take MPA at the SPSP region (i.e., considered to be fully protected, and referring to the IUCN category III) was created to protect the southern portions of the archipelago and seamounts of the Mid-Atlantic Ridge, with a total size of $47,263.18 \mathrm{~km}^{2}$. The multiple-use MPA (i.e., considered to be partially protected, and referring to the IUCN category IV) embraces the no-take one, including the majority of the small islands and a large open-ocean area, with a size of $407,052.36 \mathrm{~km}^{2}$. The no-take MPA at the TMV region (same IUCN category as the no-take MPA at the SPSP region) was created to protect portions of the shallow reef habitats and the terrestrial environment, with a size of $67,696.71 \mathrm{~km}^{2}$. This no-take is also nested within a multiple-use MPA of the same category as the SPSP described above, with a size of $402,377.1 \mathrm{~km}^{2}$. Although all these MPAs have not been fully implemented (i.e., they have not elaborated their management plans), they correspond to about $95 \%$ of the total marine area protected in Brazil. 


\section{Commercial Fishing Activity}

I used a 5-year dataset (January 2015-December 2019) of the spatial distribution of commercial fishing activity entering the study regions. The dataset was obtained from the processed VMS data provided by the National Program for tracking fishing vessels in Brazil (i.e., PREPS). The movement of fishing vessels is remotely tracked using a transponder, which transmits signals of vessel's position and behavior via satellite to ground stations on an hourly basis. To identify the behavior of vessels (e.g., navigating, fishing, and mooring), the signals are automatically processed based on spatial movement patterns and speed. I filtered out those records not associated with fishing activity and then included in the analysis only the positions by which vessels are very likely fishing. I identified a total of $1,844,902$ transmitted signals that were associated with 152 active vessels and indicative of fishing operations within the study regions over the studied period. VMS is legally required for all fishing vessels larger than $15 \mathrm{~m}$ in Brazil, which is suitable for assessing fishing pressure in remote, offshore areas.

By using a database of fishing gears associated with each vessel, I could obtain more details about the fishing operations. For example, I found that most of the fishing operations were associated with pelagic longline (i.e., $>80 \%$ ), although I also registered other fishing gears such as bait boat - pole-and-line fishing, pelagic handline, and bottom trawl (registered exclusively for the TMV region). This information requires certain caution because the type of fishing gear associated with each vessel can be modified through the renewing process of fishing licenses, without being automatically updated into the system.

I collapsed the data points from all transmitted signals for each vessel into single days to derive a metric of fishing activity (i.e., "likely fishing days") and accumulated this value for all vessels per $10 \times 10 \mathrm{~km}$ grid cell within each year assessed. I also assigned the metrics to each no-take or multiple-use MPA by overlying the MPA boundaries and fishing data. I extracted the MPA shapefiles from the dataset held by the Brazilian Ministry of Environment ${ }^{1}$. To determine the spatial similarity of total fishing days within each MPA among years, I calculated the Kendall correlation coefficient. This coefficient is a pairwise statistic that measures the degree of agreement among years.

Lastly, I summarized the following measures of fishing pressure within each MPA and year: (i) the total number of cells with fishing days $>1$ as a proxy of "fishing area"; (ii) the sum of fishing days as a proxy of "fishing intensity"; and (iii) the quotient of the total number of fishing days and the fishing area as a measure of "fishing density." Following White et al. (2020), I sought to partially control for changes in fishing pressure not related to the modification of the protection status of the study regions. For this last set of analyses, I compared each measure of fishing pressure calculated as above against the same metrics associated with cells randomly selected across Brazil's EEZ, and limited to the corresponding total size of one set of large-scale MPAs (i.e., $455,000 \mathrm{~km}^{2}$ ). I generated the random selection of cells as described in Magris et al. (2020). I restricted the cells selection within other areas of Brazil's EEZ because international

${ }^{1}$ http://www.mma.gov.br/areas-protegidas/cadastro-nacional-de-ucs waters can have different fisheries management regulations. I excluded fully-protected MPAs from the random selection as they might be effective at restricting fishing activities within their boundaries. I also allowed coastal areas to be selected because the commercial fishing fleet using the assessed gears is widely distributed across the entire Brazil's EEZ (Magris et al., 2020).

\section{RESULTS}

Considering the whole period from 2015 to 2019, I identified 28,226 total days of fishing activity in the SPSP region (93\% of them within the area of the multiple-use MPA and about $7 \%$ within the no-take one) and 54,164 in the TMV region (82\% of them within the area of the multiple-use MPA and about $18 \%$ within the no-take one).

For the SPSP region (Figure 1), I recorded a hotspot of likely fishing days on the northwestern portion of the multiple-use MPA, between the years 2015 and 2016, and on the southern portion of this MPA for the year 2017. Hotspots of fishing within the no-take MPA followed the same spatial pattern of the multiple-use one for the years prior to MPA establishment. After MPA creation, hotspots of fishing activity were well distributed in 2018 , and more spatially concentrated on the western portions of both MPAs in 2019.

For the TMV region (Figure 2), I identified that hotspots of fishing activity clustered on the central parts of the region in 2017 and were well dispersed in the previous years. After MPA establishment, large areas of the multiple-use MPA could be identified as hotspots of fishing activity, mainly in its left half, closer to the mainland. While hotspots of fishing activity were identified within no-take MPAs in 2018, fishing activity was substantially reduced in 2019 for this MPA.

When I performed the correlation matrix analysis, three results emerged (Figure 3): (i) there was no agreement between the fishing activities occurring at each year within the multipleuse MPA in the SPSP region (Kendall coefficient: $-0.09-0.14$; Figure 3A); (ii) there was a strong agreement between the fishing activities occurring at several years before and after MPA establishment within the no-take MPA in the TMV region (Kendall coefficient: 0.94-0.96; Figure 3D); and (iii) there was only a substantial agreement between the fishing activities occurring in the years 2018-2019 within the no-take MPA in the SPSP region (Kendall coefficient $=1$; Figure $3 \mathbf{B}$ ), and within the multiple-use MPA in the TMV region (Kendall coefficient $=0.67$; Figure 3C). While the first two cases imply that these specific MPAs might have little influence on the spatial patterns of fishing activity, the second situation indicates that the creation of those MPAs might have affected spatial patterns of fishing activity.

Analysis of fishing pressure within each MPA (Figure 4; top panels) revealed that the amount of fished area was reduced after MPA establishment for the SPSP region, which was not the case for the TMV region. The observed reduction in the SPSP region was followed by a decrease in the fishing intensity within the multiple-use MPA (middle panel) and an increase in the fishing density within the no-take MPA after their establishment (bottom panel). This was because fishing activity became more 

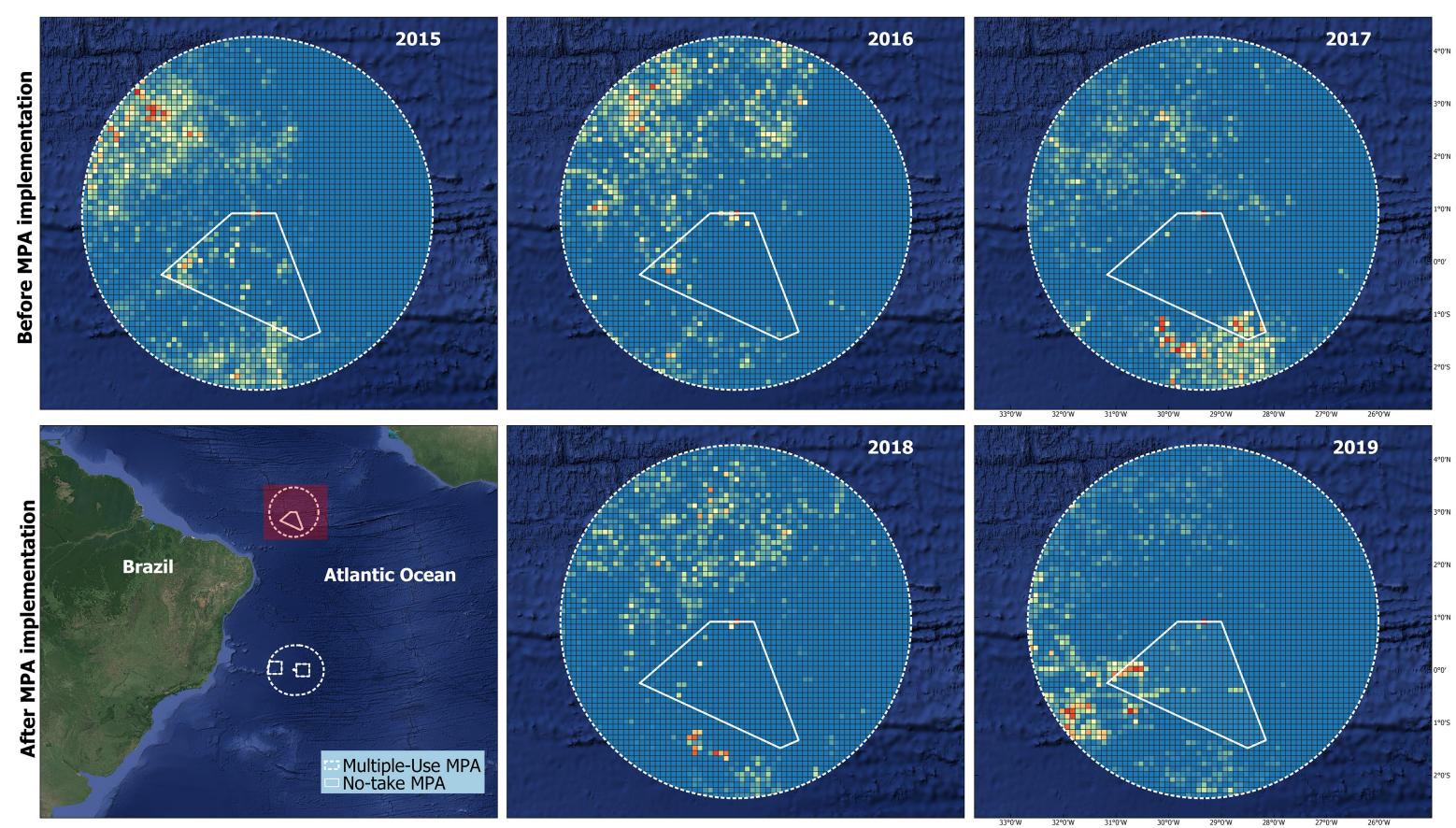

FIGURE 1 | Occurrence of fishing activity ("likely fishing days") within the no-take and multiple-use large-scale marine protected areas (MPAs) surrounding the São Pedro and São Paulo Archipelago (SPSP) over 5 years: 2015-2017 (top row), when the MPAs had not been declared; and $2018-2019$ (bottom row), when the MPAs have been established.
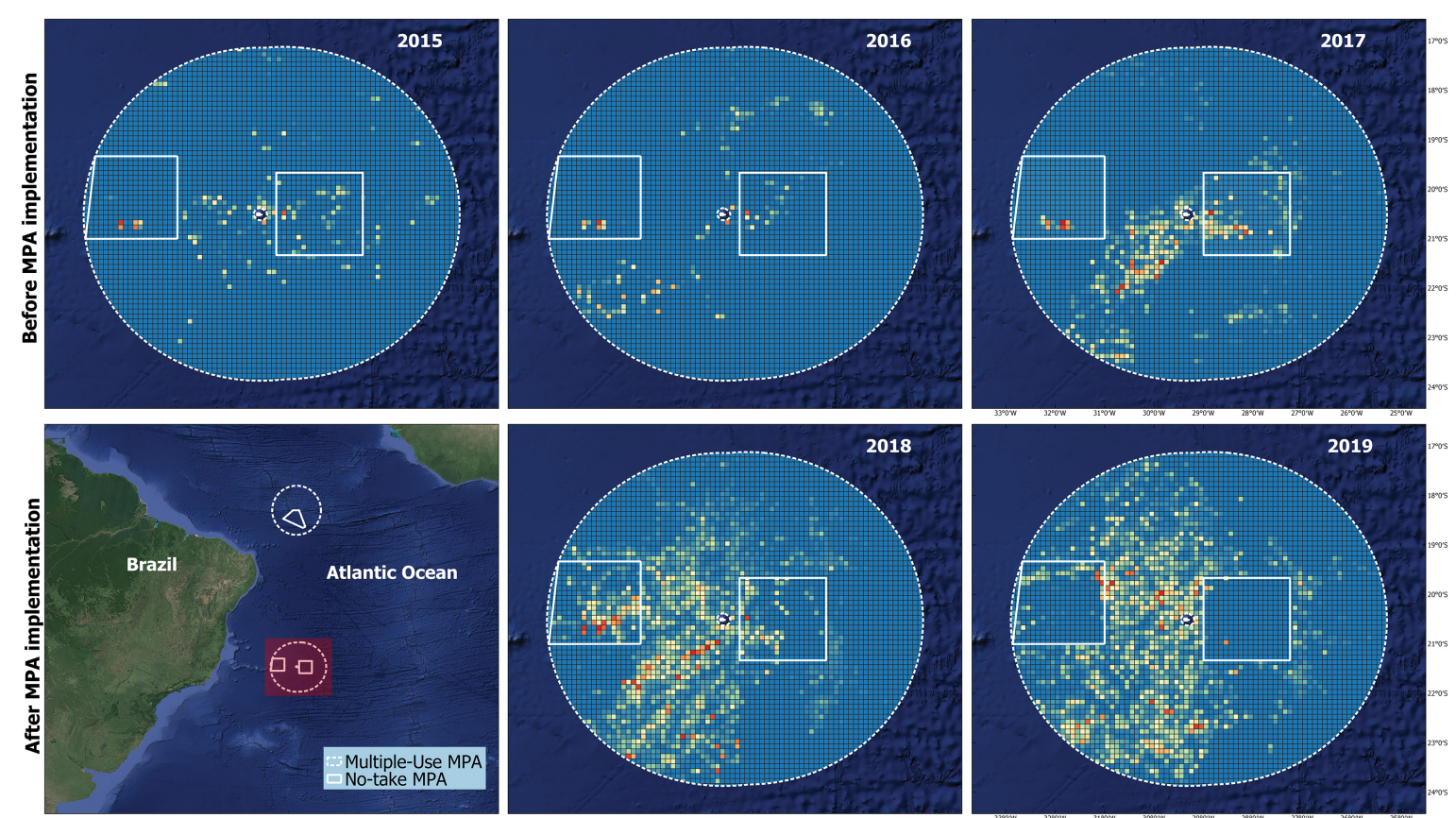

FIGURE 2 | Occurrence of fishing activity ("likely fishing days") within the no-take and the multiple-use large-scale MPAs surrounding the Trindade Island and the Martin Vaz Archipelago (TMV) over 5 years: 2015-2017 (top row), when the MPAs had not been declared; and 2018-2019 (bottom row), when the MPAs have been established. 


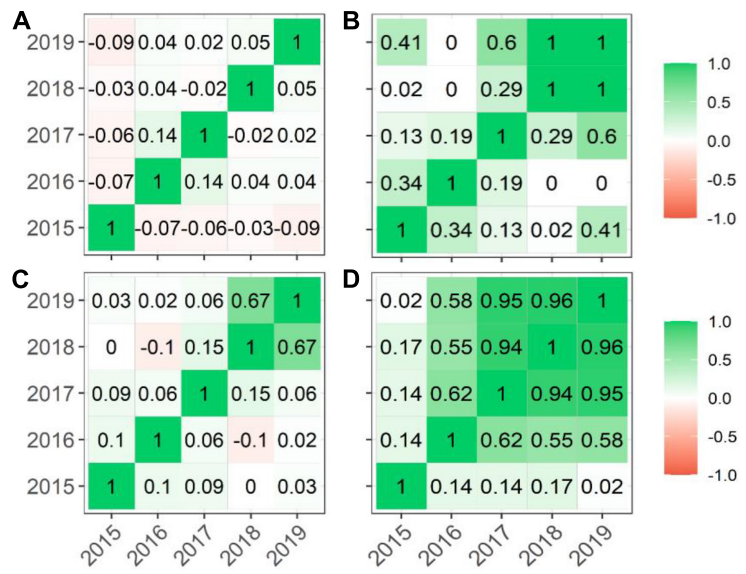

FIGURE 3 | Kendall correlation index for the relationship between fishing activity within each year for all MPAs (A: multiple-use MPA in the SPSP region; B: no-take MPA in the SPSP region; $\mathbf{C}$ : multiple-use MPA in the TMV region; and $\mathbf{D}$ : no-take MPA in the TMV region).

concentrated over smaller areas of this MPA. Overall, I also found a large increase in the fishing intensity within the multiple-use MPA for TMV (middle panel), which was also reported for the no-take MPA at least for the first year after MPA establishment (2018). When assessing the measure of fishing density for this region, I found that there was a small reduction of this measure in the no-take MPA. It was noticeable that fishing density seems not to change with MPA establishment for the multiple-use MPAs in both regions. I identified comparable and high levels of fishing pressure on the random areas that did not restrict commercial fisheries throughout the time assessed, regardless of the measure of fishing pressure used (Supplementary Figures 2-4).

\section{DISCUSSION}

The results presented here provide the first assessment of the conservation effectiveness of large-scale MPAs in the Southwestern Atlantic Ocean and contribute to the ongoing discussion about the benefits of this conservation strategy to mitigate threats from fishing (O'Leary et al., 2018). Results indicated that the effectiveness of the large-scale MPAs was variable and depended on the measure of fishing pressure used. Overall, there was a reduction in the fishing area and intensity in the SPSP region, but fishing became particularly intense over smaller areas ("squeeze factor"), particularly within the notake MPA. On the other hand, while fishing area and intensity increased for the TMV region, a reduction in the fishing density was observed because the activity became spread over larger areas. More positively, a reduction in all measures of fishing pressure became apparent in 2019 for the no-take MPA in TMV. Fishing pressure is thus significant within these large-scale MPAs and monitoring and enforcement efforts to effectively promote their reduction over time needs to be encouraged.

I estimated that between 3 and $10 \%$ of the no-take MPA in the SPSP region, and between 12 and 38\% of the no-take MPA in the TMV region remained potentially fished. This supports the existence of illegal fishing even in the remote places of the ocean as previously identified (Arias et al., 2016). Although there is some uncertainty in the VMS data to provide evidence of the magnitude of fishing activity as a result of the need to combine this technology with other forms of evidence gathering (Appleby et al., 2018), this is unlikely to change this result significantly. With the challenges associated with patrolling offshore and remote areas in the ocean, a more realistic approach to build evidence of illegal fishing would be to combine different data sources that are sufficient to lead to a prosecution, making enforcement effective.
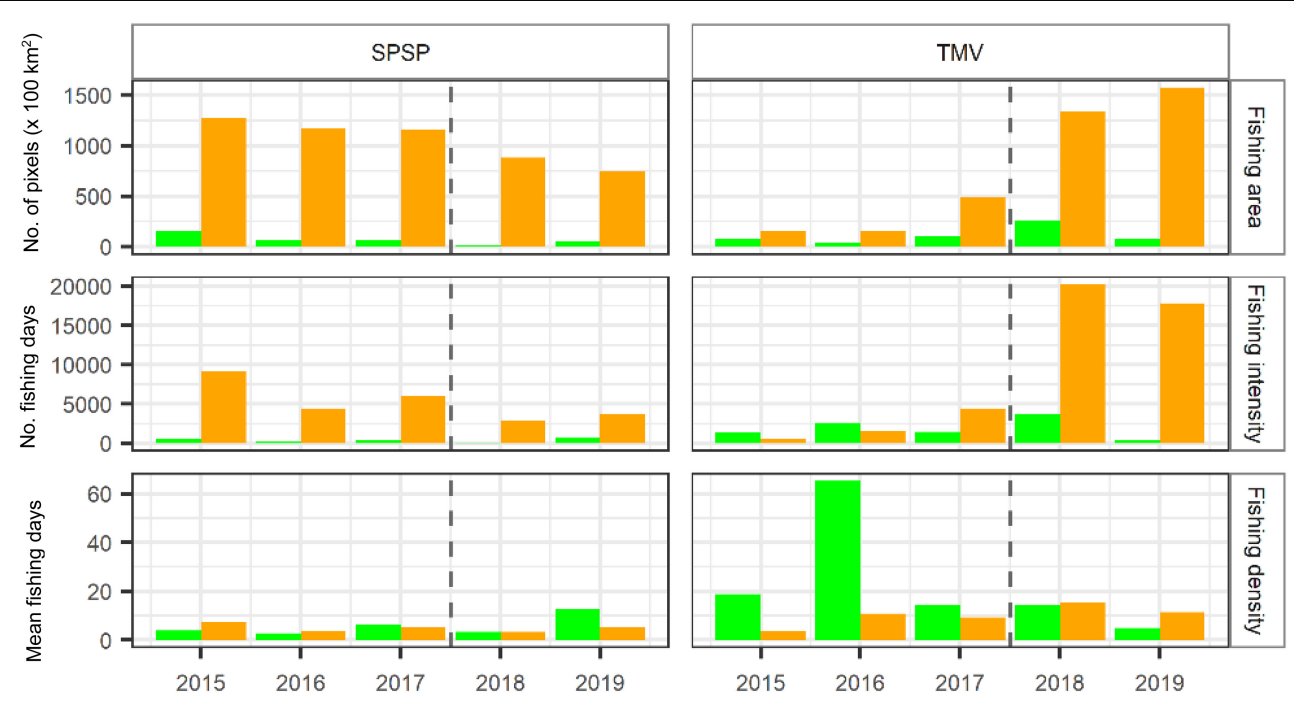

FIGURE 4 | Summaries of fishing pressure on each large-scale MPA off Brazil (green for no-take and orange for multiple-use ones) across 2015-2019 in terms of fishing area, intensity, and density. Panels on the right are results for the TMV region and on the left for the SPSP region. The dashed line indicates the time of MPA establishment. 
As previously suggested (Magris and Pressey, 2018), the effects of multiple-use, large-scale MPAs have been marginal, at least in the short term. Indeed, multiple-use MPAs have been claimed to have a limited impact on biodiversity conservation (Giakoumi et al., 2017; Zupan et al., 2018b) when assessed in terms of improving biodiversity conditions in situ. On the other hand, some have argued that their contribution to ocean conservation would be to prevent mining expansion in the future (Giglio et al., 2018; Miller et al., 2018). While these conservation outcomes are not realized, several management recommendations could be derived for this category of MPAs to improve its effectiveness in the present. Areas identified as more important for biodiversity within their boundaries (Magris et al., 2020; Vilar et al., 2020) could be targeted for more strict fishing regulations through a zoning process. Moreover, fishing activity could be particularly required to adopt practices that reduce the risk of fishing mortality (Booth et al., 2019). Strengthening regulations and establishing adequate governance are key ingredients for increasing conservation benefits expected from effective MPAs.

Recent evidence has suggested that large-scale MPAs maintain fishing levels at a low level (White et al., 2020). The results presented here do not support this pattern at least for those MPAs affording partial protection. Multiple-use MPAs did not interfere in the spatial patterns of fishing activity over the time assessed and, in some instances, fishing intensity within no-take MPAs had even increased shortly after the creation of MPAs. These contrasting findings can be explained by the intrinsic difference between the sources of fishing detection systems (VMS versus Automatic Information Systems - AIS). At least in Brazil, the AIS system misses a considerable fraction of fishing vessels, rendering assessments based on that system misleading. For example, tracking the global footprint of fisheries using AIS across the national waters off Brazil, as well as other exclusive economic zones, has shown minimal fishing effort within this area (Kroodsma et al., 2018), which is a misreport of the activity.

A major challenge to quantifying the conservation effectiveness of large-scale MPAs is the dynamic context in which threats operate over vast areas and data availability. The assessment of the threat reduction capacity of these MPAs might be influenced by other environmental conditions such as ocean currents, temperature, and distance from the mainland. Ongoing efforts to gather and analyze data for their influence on the occurrence of fishing activity will possibly result in the revised estimates of the conservation effectiveness of large-scale

\section{REFERENCES}

Almeida, A. P., Moreira, L. M. P., Bruno, S. C., Thomé, J. C. A., Martins, A. S., Bolten, A. B., et al. (2011). Green turtle nesting on trindade island, Brazil: abundance, trends, and biometrics. Endanger. Species Res. 14, 193-201. doi: 10.3354/esr00357

Appleby, T., Studley, M., Moorhouse, B., Brown, J., Staddon, C., and Bean, E. (2018). Sea of possibilities: old and new uses of remote sensing data for the enforcement of the Ascension Island marine protected area. Mar. Policy 127:103184. doi: 10.1016/j.marpol.2018.06.012

Arias, A., Pressey, R. L., Jones, R. E., Álvarez-Romero, J. G., and Cinner, J. E. (2016). Optimizing enforcement and compliance in offshore marine protected
MPAs, allowing more comprehensive assessments of their role in reducing fishing pressure.

Though there are venues for further development and refinement, this study constitutes an important first step in quantifying the effects of large-scale MPAs off Brazil. The case study highlights that, unlike other regions, fishing activity remains operating within multiple-use MPAs, and that avoiding illegal fishing within no-take MPAs is an urgent need. While remote sensing technologies provide spatially and temporally continuous assessment of fishing activities, it would need to be combined with other evidence-based tools on fishing effort for increasing existing levels of compliance and enforcement. The variations in fishing pressure among MPA types over time affirm the dynamic nature of managing offshore marine systems.

\section{DATA AVAILABILITY STATEMENT}

The processed data supporting the conclusions of this article will be made available by the authors, without undue reservation.

\section{AUTHOR CONTRIBUTIONS}

RAM was the sole author of this manuscript, developed the research question and protocol, conducted data collection and analysis, and wrote the content of the manuscript.

\section{ACKNOWLEDGMENTS}

The author thanks all delegates, volunteers, and sponsors of IMCC6 for enthusiastically supporting the online conference and all staff of the MPAs studied here for insightful comments on the results. The author also thanks Charlotte Sève and Joaquim Claudet for inviting him to present at the session "Recent innovations in marine protected area networks design and assessment."

\section{SUPPLEMENTARY MATERIAL}

The Supplementary Material for this article can be found online at: https://www.frontiersin.org/articles/10.3389/fmars. 2021.711011/full\#supplementary-material

areas: a case study from Cocos Island, Costa Rica. Oryx 50, 18-26. doi: 10.1017/ S0030605314000337

Ban, N. C., Davies, T. E., Aguilera, S. E., Brooks, C., Cox, M., Epstein, G., et al. (2017). Social and ecological effectiveness of large marine protected areas. Glob. Environ. Change 43, 82-91. doi: 10.1016/j.gloenvcha.2017. 01.003

Boonzaier, L., and Pauly, D. (2016). Marine protection targets: an updated assessment of global progress. Oryx 50, 27-35. doi: 10.1017/ S0030605315000848

Booth, H., Squires, D., and Milner-Gulland, E. J. (2019). The neglected complexities of shark fisheries, and priorities for holistic risk-based management. Ocean Coast. Manag. 182:104994. doi: 10.1016/j.ocecoaman.2019.104994 
Booth, H., Squires, D., and Milner-Gulland, E. J. (2020). The mitigation hierarchy for sharks: a risk-based framework for reconciling trade-offs between shark conservation and fisheries objectives. Fish Fish. 21, 269-289. doi: 10.1111/faf. 12429

Brooks, C. M., Epstein, G., and Ban, N. C. (2019). Managing marine protected areas in remote areas: the case of the subantarctic heard and McDonald Islands. Front. Mar. Sci. 6:631. doi: 10.3389/fmars.2019.00631

Chang, S. K., and Yuan, T. L. (2014). Deriving high-resolution spatiotemporal fishing effort of large-scale longline fishery from vessel monitoring system (VMS) data and validated by observer data. Can. J. Fish. Aquat. Sci. 71, 1363-1370. doi: 10.1139/cjfas-2013-0552

Claudet, J., Loiseau, C., and Pebayle, A. (2021). Critical gaps in the protection of the second largest exclusive economic zone in the world. Mar. Policy 124:104379. doi: 10.1016/j.marpol.2020.104379

de Oliveira Júnior, J. G. C., Campos-Silva, J. V., Santos, D. T. V., Ladle, R. J., and da Silva Batista, V. (2021). Quantifying anthropogenic threats affecting marine protected areas in developing countries. J. Environ. Manag. 279:111614. doi: 10.1016/j.jenvman.2020.111614

De Santo, E. M. (2013). Missing marine protected area (MPA) targets: how the push for quantity over quality undermines sustainability and social justice. J. Environ. Manag. 124, 137-146. doi: 10.1016/j.jenvman.2013.01.033

Delfour-Samama, O., and Leboeuf, C. (2014). Review of potential legal frameworks for effective implementationand enforcement of MPAs in the high seas. ICES J. Mar. Sci. 278:97. doi: 10.1038/278097a0

Duarte-Neto, P., Higa, F. M., and Lessa, R. P. (2012). Age and growth estimation of bigeye tuna, Thunnus obesus (Teleostei: Scombridae) in the southwestern Atlantic. Neotrop. Ichthyol. 10, 149-158. doi: 10.1590/s167962252012000100014

Dulvy, N. K., Fowler, S. L., Musick, J. A., Cavanagh, R. D., Kyne, P. M., Harrison, L. R., et al. (2014). Extinction risk and conservation of the world's sharks and rays. Elife 3, 1-34. doi: 10.7554/elife.00590

Friedlander, A. M., Wagner, D., Gaymer, C. F., Aulani Wilhelm, T., Lewis, N., Brooke, S., et al. (2016). Co-operation between large-scale MPAs: successful experiences from the Pacific Ocean. Aquat. Conserv. Mar. Freshw. Ecosyst. 26, 126-141. doi: 10.1002/aqc. 2645

Giakoumi, S., Scianna, C., Plass-Johnson, J., Micheli, F., Grorud-Colvert, K., Thiriet, P., et al. (2017). Ecological effects of full and partial protection in the crowded Mediterranean Sea: a regional meta-analysis. Sci. Rep. 7, 1-12. doi: 10.1038/s41598-017-08850-w

Giglio, V. J., Pinheiro, H. T., Bender, M. G., Bonaldo, R. M., Costa-Lotufo, L. V., Ferreira, C. E. L., et al. (2018). Large and remote marine protected areas in the South Atlantic Ocean are flawed and raise concerns: comments on Soares and Lucas (2018). Mar. Policy 96, 13-17. doi: 10.1016/j.marpol.2018.07.017

Kaiser, M. J., Collie, J. S., Hall, S. J., Jennings, S., and Poiner, I. R. (2002). Modification of marine habitats by trawling activities: prognosis and solutions. Fish Fish. 3, 114-136. doi: 10.1046/j.1467-2979.2002.00079.x

Kroodsma, D. A., Mayorga, J., Hochberg, T., Miller, N. A., Boerder, K., Ferretti, F., et al. (2018). Tracking the global footprintof fisheries of Fisheries. Science 359, 904-908.

Lubchenco, J., and Grorud-Colvert, K. (2015). Making waves: the science and politics of ocean protection. Science 350, 382-385. doi: 10.1126/science.aad 5443

Lundquist, C. J., Bowden, D., Cartner, K., Stephenson, F., Tuck, I., and Hewitt, J. E. (2018). Assessing benthic responses to fishing disturbance over broad spatial scales that incorporate high environmental variation. Front. Mar. Sci. 5:405. doi: 10.3389/fmars.2018.00405

Magris, R. A., Costa, M. D. P., Ferreira, C. E. L., Vilar, C. C., Joyeux, J.-C., Creed, J. C., et al. (2020). A blueprint for securing Brazil's marine biodiversity and supporting the achievement of global conservation goals. Divers. Distrib. 27, 198-215. doi: 10.1111/ddi.13183

Magris, R. A., and Pressey, R. L. (2018). Marine protected areas: just for show? Science 360, 723-724. doi: 10.1126/science.aat6215

Miller, K. A., Thompson, K. F., Johnston, P., and Santillo, D. (2018). An overview of seabed mining including the current state of development, environmental impacts, and knowledge gaps. Front. Mar. Sci. 4:418. doi: 10.3389/fmars.2017. 00418

Morais, R. A., Ferreira, C. E. L., and Floeter, S. R. (2017). Spatial patterns of fish standing biomass across Brazilian reefs. J. Fish Biol. 91, 1642-1667. doi: $10.1111 /$ jfb. 13482
Mumby, P. J., Dahlgren, C. P., Harborne, A. R., Kappel, C. V., Micheli, F., Brumbaugh, D. R., et al. (2006). Fishing, trophic cascades, and the process of grazing on coral reefs. Science 311, 98-101. doi: 10.1126/science.1121129

O’Leary, B. C., Ban, N. C., Fernandez, M., Friedlander, A. M., García-Borboroglu, P., Golbuu, Y., et al. (2018). Addressing criticisms of large-scale marine protected areas. BioScience 68, 359-370. doi: 10.1093/biosci/biy021

Pajaro, M. G., Mulrennan, M. E., Alder, J., and Vincent, A. C. J. (2010). Developing MPA effectiveness indicators: comparison within and across stakeholder groups and communities. Coast. Manag. 38, 122-143. doi: 10.1080/ 08920751003633094

Pinheiro, H. T., Macena, B. C. L., Francini-Filho, R. B., Ferreira, C. E. L., Albuquerque, F. V., Bezerra, N. P. A., et al. (2020). Fish biodiversity of Saint Peter and Saint Paul's archipelago, Mid-Atlantic Ridge, Brazil: new records and a species database. J. Fish Biol. 97, 1143-1153. doi: 10.1111/jfb.14484

Pomeroy, R. S., Watson, L. M., Parks, J. E., and Cid, G. A. (2005). How is your MPA doing? A methodology for evaluating the management effectiveness of marine protected areas. Ocean Coast. Manag. 48, 485-502. doi: 10.1016/j.ocecoaman. 2005.05.004

Roberts, K. E., Valkan, R. S., and Cook, C. N. (2018). Measuring progress in marine protection: a new set of metrics to evaluate the strength of marine protected area networks. Biol. Conserv. 219, 20-27. doi: 10.1016/j.biocon.2018.01.004

Rowlands, G., Brown, J., Soule, B., Boluda, P. T., and Rogers, A. D. (2019). Satellite surveillance of fishing vessel activity in the Ascension Island exclusive economic zone and marine protected area. Mar. Policy 101, 39-50. doi: 10.1016/j.marpol. 2018.11.006

Sala, E., Mayorga, J., Costello, C., Kroodsma, D., Palomares, M. L. D., Pauly, D., et al. (2018). The economics of fishing the high seas. Sci. Adv. 4, 1-14. doi: 10.1126/sciadv.aat2504

Shears, N. T., Babcock, R. C., and Salomon, A. K. (2008). Context-dependent effects of fishing: variation in trophic cascades across environmental gradients. Ecol. Appl. 18, 1860-1873. doi: 10.1890/07-1776.1

Simon, T., Macieira, R. M., and Joyeux, J. C. (2013). The shore fishes of the Trindade-martin Vaz insular complex: an update. J. Fish Biol. 82, 2113-2127. doi: $10.1111 /$ jfb. 12126

Vilar, C. C., Magris, R. A., Loyola, R., and Joyeux, J.-C. (2020). Strengthening the synergies among global biodiversity targets to reconcile conservation and socio-economic demands. Aquat. Conserv. Mar. Freshw. Ecosyst. 30, 497-513. doi: 10.1002/aqc.3269

White, T. D., Carlisle, A. B., Kroodsma, D. A., Block, B. A., Casagrandi, R., De Leo, G. A., et al. (2017). Assessing the effectiveness of a large marine protected area for reef shark conservation. Biol. Conserv. 207, 64-71. doi: 10.1016/j.biocon. 2017.01.009

White, T. D., Ong, T., Ferretti, F., Block, B. A., McCauley, D. J., Micheli, F., et al. (2020). Tracking the response of industrial fishing fleets to large marine protected areas in the Pacific Ocean. Conserv. Biol. 34, 1571-1578. doi: 10.1111/ cobi. 13584

Zupan, M., Bulleri, F., Evans, J., Fraschetti, S., Guidetti, P., Garcia-Rubies, A., et al. (2018a). How good is your marine protected area at curbing threats? Biol. Conserv. 221, 237-245. doi: 10.1016/j.biocon.2018.03.013

Zupan, M., Fragkopoulou, E., Claudet, J., Erzini, K., Horta e Costa, B., and Gonçalves, E. J. (2018b). Marine partially protected areas: drivers of ecological effectiveness. Front. Ecol. Environ. 16:381-387. doi: 10.1002/fee.1934

Conflict of Interest: The author declares that the research was conducted in the absence of any commercial or financial relationships that could be construed as a potential conflict of interest.

Publisher's Note: All claims expressed in this article are solely those of the authors and do not necessarily represent those of their affiliated organizations, or those of the publisher, the editors and the reviewers. Any product that may be evaluated in this article, or claim that may be made by its manufacturer, is not guaranteed or endorsed by the publisher.

Copyright (c) 2021 Magris. This is an open-access article distributed under the terms of the Creative Commons Attribution License (CC BY). The use, distribution or reproduction in other forums is permitted, provided the original author(s) and the copyright owner(s) are credited and that the original publication in this journal is cited, in accordance with accepted academic practice. No use, distribution or reproduction is permitted which does not comply with these terms. 